УДК 378.091.4:37.018.1(477.82)

DOI https://doi.org/10.32782/apv/2021.3.17

\title{
Ігор ОСТАПЙОВСЬКИЙ
}

кандидат педагогічних наук, доцент кафедри загальної педагогіки та дошкільної освіти, Волинський національний університет імені Лесі Украӥнки, просп. Волі, 13, м. Луиьк, Волинська область, Україна, 43025

ORCID: 0000-0001-7152-4168

\section{Тетяна ОСТАПЙОВСЬКА}

кандидат педагогічних наук, доцент кафедри теорії і методики початкової освіти, Волинський національний університет імені Лесі Українки, просп. Волі, 13, м. Луцьк, Волинська область, Україна, 43025

ORCID: 0000-0003-4404-8586

Біографічний опис статті: Остапйовський, І., Остапйовська, Т. (2021). Батьківська педагогіка як важливий чинник забезпечення партнерської взаємодії закладу освіти й сім’їв спадщині В.О. Сухомлинського. Acta Paedagogica Volynienses, 3, 113-119, doi: https://doi.org/10.32782/apv/2021.3.17

\section{БАТЬКІВСЬКА ШКОЛА ЯК ВАЖЛИВИЙ ЧИННИК ЗАБЕЗПЕЧЕННЯ ПАРТНЕРСЬКОЇ ВЗАСМОДІЇ ЗАКЛАДУ ОСВІТИ Й СІМ’̈̈ В СПАДЩИНІ В.О. СУХОМЛИНСЬКОГО}

Важливою для сучасної педагогічної науки та шкільної практики є проблема педагогіки партнерства. Їі теоретичну та практичну значущість обтрунтовано у Концепції Нової украӥнської школи. Аналіз історико-педагогічних джерел засвідчує, щз ще у минулому столітті ї̈ було успішно реалізовано видатним вітчизняним педагогом Василем Олександровичем Сухомлинським. Необхідною умовою у здійсненні педагогіки партнерства, за Сухомлинським, є єдність дій сім'ї та школи щзодо навчання, виховання та розвитку школярів. Формувалася спільність дій сім'ї та школи в процесі оволодівання батьком та матір'ю батьківською педагогікою, знаннями якої вони оволодівали у школі для батьків.

Мета роботи. За результатами аналізу педагогічної спадщзини В.О. Сухомлинського розкрити сутність батьківської школи як важливого чинника у забезпеченні партнерської взаємодії між закладом освіти та сім'єю.

Методологічною основою дослідження є наукові підходи (концептуальний, системний, аспектний, діалектичний, компетентнісний), принципи(науковості, об'єктивності, розвитку, практичності, історизму ); нормативно-законодавча база у сфері освіти; Концепція Нової украӥнської школи; твори В.О. Сухомлинського; праці науковиів про В.О. Сухомлинського.

Для реалізації мети дослідження було також використано методи порівняльно - історичний, аналізу, синтезу, узагальнення, систематизації, інтерпретаиії.

Наукова новизна дослідження. За результатами наукового пошуку обтрунтовано сутність батьківської педагогіки і умови ефективної взаємодії сім'ї та школи у творчому доробку вченого. Розкрито особливості та форми організації діяльності школи для батьків в спадщині В. Сухомлинського. Розвитку набуло вчення педагога про батьківську любов та висвітлення згубного впливу любові замилування, деспотичної $і$ відкупу. Визначенні перспективності ідей В.О. Сухомлинського.

Висновки. Важливою складовою частиною у творчому доробку Сухомлинського є партнерська взаємодія сім' $і$ та школи. Умовою иього партнерства є оволодівання сім'єю батьківською педагогікою. Опанування батьківської педагогіки та визначення стратегї спільної діяльності сім'ї та школи відбувалося на заняттях школи для батьків.

Ключові слова: В.О. Сухомлинський, батьківська школа, сім'я, педагогіка партнерства.

\section{Igor OSTAPIOVSKYI}

Candidate of Pedagogic Sciences, Senior Lecturer at the Department of General Pedagogy and Preschool Education, Lesya Ukrainka Volyn National University, 13 Voli Ave, Lutsk, Volyn region, Ukraine, 43025

ORCID: 0000-0001-7152-4168 


\section{Tatiana OSTAPIOVSKA}

Candidate of Pedagogic Sciences, Senior Lecturer at the Department of Theory and Methods of Primary Education, Lesya Ukrainka Volyn National University, 13 Voli Ave, Lutsk, Volyn region, Ukraine, 43025

ORCID: 0000-0003-4404-8586

To cite this article: Ostapiovskyi, I., Ostapiovska, T. (2021). Batkivska shkola yak vazhlyvyi chynnyk zabezpechennia partnerskoi vzaiemodii zakladu osvity ta simi u spadshchyni V.O. Sukhomlynskoho [Parental pedagogy as an important factor in ensuring partnership between the educational institution and the family in the legacy of V.O. Sukhomlinskyi]. Acta Paedagogica Volynienses, 3, 113-119, doi: https://doi.org/10.32782/apv/2021.3.17

\section{PARENTAL PEDAGOGY AS AN IMPORTANT FACTOR IN ENSURING PARTNERSHIP BETWEEN THE EDUCATIONAL INSTITUTION AND THE FAMILY IN THE LEGACY OF V.O. SUKHOMLINSKYI}

The problem of partnership pedagogy is important for modern pedagogical science and school practice. Its theoretical and practical significance is substantiated in the Concept of the New Ukrainian School. The analysis of historical and pedagogical sources shows that in the last century it was successfully implemented by an outstanding domestic teacher Vasyl Oleksandrovych Sukhomlynskyi. A necessary condition for the implementation of partnership pedagogy, according to Sukhomlynskyi, is the unity of action of the family and the school for the education, upbringing and development of students. The joint actions of the family and the school were formed in the process of mastering parental pedagogy by the father and mother, the knowledge of which they mastered in the school for parents.

The goal of the article. According to the results of the analysis of the pedagogical heritage of $V$. O. Sukhomlynskyi to reveal the essence of the parent school as an important factor in ensuring partnership between the educational institution and the family.

The methodological basis of the research is scientific approaches (conceptual, systemic, aspectual, dialectical, competence), principles (scientificity, objectivity, development, practicality, historicism); regulatory framework in the field of education; The concept of the New Ukrainian School; works by V. O. Sukhomlynskyi; works of scientists about V. O. Sukhomlynskyi.

To achieve the purpose of the study, comparative methods were also used: historical, analysis, synthesis, generalization, systematization, interpretation.

Scientific novelty of the research. The results of scientific research substantiate the essence of parental pedagogy and the conditions of effective interaction between family and school in the creative work of the scientist. Features and forms of organization of school activities for parents in the legacy of Sukhomlynskyi are revealed. The teacher\&apos; $S$ teaching on parental love and the coverage of the destructive effects of love of admiration, despotism and redemption were developed. Determining the prospects of the ideas of V. O. Sukhomlynskyi.

Conclusions. An important component of Sukhomlynskyi's creative work is the partnership between family and school. The condition of this partnership is the mastery of parental pedagogy by the family. Mastering parental pedagogy and defining the strategy of joint activities of family and school took place in school classes for parents.

Key words: V. O. Sukhomlynskyi, parent school, family, partnership pedagogy.

Актуальність проблеми. Сьогодення вимагає від кожної людини бути компетентною, мобільною, здатної до ефективної взаємодії із оточенням. Це дозволить ії безболісно влитися у соціум, засвоїти його цінності та досвід, розвиватися як індивід, особистість, індивідуальність. Такий процес відбувається ціле свідоме життя. Містить він первинну (дитинство та юність), так і вторинну (зрілість) соціалізацію. Її результативність визначається впливом різноманітних факторів (мега, макро, мезо, мікро). Усі вони важливі, але найбільш дієвими, 3 якими стикається кожний школяр, є мікрофактори - сім'я та школа.

Перший життєвий досвід дитина отримує у сім'ї. Надалі він набуває розвитку в закла- дах загальної середньої освіти. Здійснюючи виховні впливи та забезпечуючи розвиток особистості сім'я та школа повинні бути однодумцями та партнерами. Невипадково, одним із ключових компонентів Нової української школи є педагогіка партнерства (Нова українська школа: порадник для вчителя, 2019, с. 17-18).

Забезпечення партнерської взаємодії немислиме без педагогізації сім'ї. Саме тому таке питання є надзвичайно важливим в історії педагогічної думки. Його розробляли відомі зарубіжні та вітчизняні вчені. Не втратили актуальності для сьогодення роботи Я. А. Коменського (Коменский, 1989), Й. Г. Песталоцці (Песталоцци, 1989), К. Д. Ушинського (Ушин- 
ский, 1968), А. С. Макаренка (Макаренко, 1980) та ін. У них обгрунтовано важливість сімейного виховання, розроблено методичні настанови щодо організації навчання та виховання дітей у сім'ї.

Аналіз історико-педагогічних джерел та сучасної наукової літератури дозволяє стверджувати, що у педагогічній науці ще недостатньо розроблено конкретні рекомендації щодо організації та реалізації партнерської взаємодії між школою та сім'єю. Натомість досить грунтовно проблему розкрито у творчому доробку відомого вітчизняного педагога Василя Олександровича Сухомлинського.

Актуальність проблематики зумовила вибір теми нашого дослідження: «Батьківська школа як важливий чинник забезпечення партнерської взаємодії закладу освіти та сім'ї у спадщині В.О. Сухомлинського».

Аналіз останніх досліджень і публікацій. Ідеї українського педагога В. О. Сухомлинського не втратили актуальності із плином часу. До його спадщини звертаються багато дослідників. Найвагоміший внесок у дослідження творчості відомого педагога зроблено академіком Ольгою Василівною Сухомлинською. Аналізуючи творчий доробок Василя Олександровича, О. В. Сухомлинська, оперуючи першоджерелами, розкриває актуальність ідей В.О. Сухомлинського в умовах сьогодення (Сухомлинська, 2018). Для Президента АПН України В. Кременя педагогіка Сухомлинського є відповіддю на вимоги часу, особливої значущості набувають ідеї дитиноцентризму, сімейного виховання, педагогізації сім’ї (Кремень, 2018). Дослідивши розвиток ідеї материнської любові від Коменського до Сухомлинського, О. Петренко розкриває внесок вченого у розвиток сімейного виховання в цілому, та материнської любові зокрема (Петренко, 2018). Різноманітні аспекти реалізації педагогіки партнерства у педагогічній спадщині В.О. Сухомлинського була предметом дослідження І. Білецької, О. Коберник (Білецька, Коберник, 2018), Н. Мельник (Мельник, 2019), I. Остапйовського, Т. Остапйовської (Остапйовський, Остапйовська, 2020). Відповідність ідей В.О. Сухомлинського реаліям розбудови нової української школи досліджували М. Друганова та О. Білик (Драгунова, Білик, 2019).

Мета дослідження. За результатами аналізу педагогічної спадщини В. О. Сухомлинського розкрити сутність батьківської школи як важливого чинника у забезпеченні партнерської взаємодії між закладом освіти та сім'єю.

\section{Виклад основного матеріалу дослідження.}

Важливим пріоритетом в діяльності сучасної школи є забезпечення партнерської взаємодії зі сім'єю. Однією із умов реалізації спільної діяльності сім'ї та школи на партнерських засадах $\epsilon$ оволодіння батьком та матір'ю батьківською педагогікою. Відповіді на питання про сутність батьківської педагогіки можна почерпнути у творчій спадщині Василя Олександровича Сухомлинського.

Вивчення наукових праць вченого дозволяє стверджувати, що батьківська педагогіка, за Сухомлинським, $є$ елементарним колом знань матері та батька про те, як істота, що народилася від людини, стає людиною (Сухомлинський, 1976, с. 535-536). Ці знання вони мали можливість отримати у педагогічній школі для батьків. У структурі цієї школи функціонували чотири відділи. Це дошкільний відділ, відділ для батьків учнів першого - третього класів, четвертого - восьмого класів та дев'ятого і десятого класів. Навчальний процес у батьківській школі передбачав, що навчалися в школі батько та мати школяра. Своє навчання вони розпочинали за три роки до того, як віддати своїх дітей на навчання. Заняття для батьків проводилися два рази на місяць. Ці заняття проводили директор школи, заступник директора з навчально-виховної роботи, заступник із позакласної роботи та вчитель, який через три роки навчатиме першокласників.

Навчання батьків $\epsilon$ нелегкою справою. 3 метою уникнення помилок та забезпечення ефективності такого процесу, В.О. Сухомлинським розроблено ряд рекомендацій. Однієї із них $є$ порада, яка передбачає провести заняття таким чином, щоб пробудити в батька та матері почуття гордості від того, що вони творять найпрекрасніше, найблагородніше на землі. Тим самим розкрити батьківську педагогіку як працю, науку, майстерність та творчість (Сухомлинський, 1976, с. 537).

Щоб не відштовхнути батьків від школи, не посіяти у них зневіри у можливості виховання власних дітей, Василь Олександрович не рекомендує проводити заняття у формі «вивертання душі», «перероблення батьків, що допускають, помилки та прорахунки у вихованні». Таку 
позицію він аргументує тим, що розмовляючи з батьками про їхніх дітей, ми мовби примушуємо їх подивитися у дзеркало. Тому не важко спрогнозувати реакцію людини, якій скажуть: подивіться, який ви потворний... (Сухомлинський, 1976, с. 538).

Така порада ніяк не означає, що «гострі кути» у вихованні Сухомлинський радить обходити або згладжувати. Їх, на його думку, необхідно вміло, тактовно, без окриків та метушні розв'язувати, не принижуючи та паплюжачи людину. Тому, якщо доводиться привселюдно говорити про погане, то непотрібно називати прізвища батьків, які допустили необачність або помилку у вихованні.

Аналіз творчого доробку В.О. Сухомлинського засвідчує, що для глибокого аналізу про помилки та прорахунки в умовах конкретної сім’ї в діяльності батьківської школи використовували індивідуальні бесіди з батьками. Такі бесіди 3 матерями проводили педагоги-жінки, а $з$ батьками - чоловіки-педагоги.

В діяльності педагогічної школи важливою формою роботи були також індивідуальні бесіди з матір'ю та батьком - бесіди без дітей. Індивідуальний характер бесід був продиктований специфікою сімейного життя. Відсутність дітей була зумовлена тим, що відкриття труднощів, незгод та невдач у вихованні, окрім шкоди нічого іншого для них не принесе. Оскільки дітей, на думку Сухомлинського, виховує саме те, що в сім'ї все добре, а добро, злагода, взаємна повага, любов і поступливість батьків $\epsilon$ головною силою виховного впливу.

Ефективність занять батьківської школи у діяльності В.О. Сухомлинського забезпечувалася творчим використанням різноманітних форм організації спільної діяльності педагогів школи із батьками школярів. Однією із них були лекції для батьків. У лекціях Сухомлинський спільно із вчителями школи навчали батьків, як правильно виховувати дітей, зміцнювати і берегти здоров'я дитини, розвивати мову, розумові здібності, виховувати любов до праці, навчання, запобігати нервовим захворюванням та ін.

Підтвердженням цього є тематика лекцій для батьків учнів першого та другого класів, проведена у 1969-1970 навчальному році. Вона містила питання фізичного та психічного розвитку дитини; типу нервової системи і дитячого тем- пераменту; режиму праці, харчування та відпочинку; здоров'я і розумового розвитку дитини; духовного життя сім'ї і виховання дитини; рідної мови та іiі ролі у перші роки шкільного навчання; поведінки дитини семи - дев'яти років і виховання громадянського обов'язку; запобіганню нервовим захворюванням у процесі навчання; ролі природи в розвитку мислення і в моральному вихованні; краси і їі ролі у розвитку мислення і мови дитини; засвоєння етичних норм; книги в сім'ї та духовного розвитку дитини; засвоєння етичних норм; трудового виховання в сім'ї; вихованню духовних інтересів та потреб; вихованню дисциплінованості та почуття обов'язку; взаємин матері та батька і виховання дитини; вимогливості і поваги до дитини; вихованню культури поведінки; відповідальності батьків за виховання; першим крокам самовиховання та ін. (Сухомлинський, 1976, c. 445).

Педагогіка Сухомлинського глибоко гуманна. Багато ідей Василя Олександровича випередили час i $\epsilon$ актуальними сьогодні. У двадцять першому столітті в українському суспільстві утвердилася думка про необхідність створення безбар'єрного доступу дітей iз особливими освітніми потребами до реалізації свого права на освіту і здобуття іiі за місцем проживання в умовах загальноосвітнього закладу. Сухомлинський розвиває таку ідею ще у сімдесятих роках двадцятого століття. Він вважав великим успіхом створення в батьківській школі групи батьків і матерів тих учнів, які мали вади у розумовому розвитку. Діяльності цієї групи батьків Василь Олександрович надавав винятково великого значення. Він вважав, що від того як навчаються ці діти, чи зуміють педагоги дати їм щастя дитинства, залежить загальна моральна атмосфера школи та дух поваги до людини. У навчальних закладах, де діти полишені на одинці зі своїми проблемами, де вони почуваються скривдженими, не може бути міцного учнівського колективу та нормальних взаємовідносин між педагогами і школярами.

Актуальною для сьогодення є думка Сухомлинського, що головним завданням педагогів та батьків дітей, які мають відхилення у розумовому розвитку, $\epsilon$ забезпечення розвитку їхніх розумових здібностей, а не оволодіння ними певним колом знань. Розв'язати таке 
завдання, сформувати партнерську взаємодію в діяльності педагогів із батьками цих дітей були покликанні заняття батьківської школи. Тематикою таких занять передбачалося розгляд питань інтелектуальної культури сім’і та розумового розвитку дитини; стимулів, що спонукають дитину до розумової праці; мислення дитини; ролі казки у розвитку малоздібної дитини; алкоголізму і розумового розвитку дітей; емоційного виховання і розумового розвитку; художнього мислення; розвитку пам'яті; природи в розумовому розвитку дітей, які стоять на грані аномалій; краси в розумовому розвитку дітей; розумових вправ для дітей, які стоять на грані аномалій; проведення розумових вправ у сім'ї; методичного керівництва до проведення розумових вправ; інтелектуального та емоційного змісту казок і оповідань, спеціально призначених для аномальних дітей; розумових захоплень дітей; інтелектуальних нахилів дітей, які повільно думають; успіху у розумовій праці; інтелектуальних почуттів та їх пробудження; формування інтелектуальних нахилів; що можна і чого не можна вимагати від дітей, які стоять на грані розумових аномалій; творчої праці дітей; творчості словом (складання казок, оповідань), як засобу розвитку розумових здібностей дітей; режиму праці, відпочинку, харчування; лікувального харчування; грані аномального і нормального розумового розвитку (Сухомлинський, 1976, с. 446).

Вивчаючи спадщину видатного педагога переконуємося, що джерелом успіхів у справі виховання підростаючих поколінь була співпраця зі сім'єю. Тому педагогічний колектив Павлиської середньої школи та батьки, як два скульптори, працювали поряд, мали єдине уявлення про ідеал і працювали в одному напрямку. У гармонії творення людини, писав Василь Олександрович, надзвичайно важливо, щоб у двох скульпторів не було протилежних позицій, щоб у матері та батька було єдине уявлення про те, кого вони разом зі школою виховують, а звідси і про єдність вимог, передусім до самих себе (Сухомлинський, 1976, с. 542). Добитися такої єдності, на глибоке переконання Сухомлинського, можливо за умови, коли матерів та батьків навчити мудрості батьківської педагогіки, яка дозволить їм опанувати мудрістю материнської та батьківської любові. Без мудрості батьківської педагогіки, на думку
Василя Олександровича, любов матері й батька калічить дітей. На конкретних прикладах педагог демонструє згубний вплив на виховання дітей любові замилування, деспотичної любові та любові відкупу (Сухомлинський, 1976, c. $542-545)$.

Любов замилування є нерозумною інстинктивною любов'ю. Її ще Сухомлинський називав курячою любов'ю. Для дитини, вихованої в дусі такої любові, незрозумілими та чужими $\epsilon$ поняття «можна», «не можна», «треба». Вони переконанні, що для них усе можна. Як правило ці діти є примхливими, хворобливими, егоїстичними. Найменші труднощі для них $є$ непосильним тягарем. Вони не вміють і не бажають трудитися, не помічають і не відчувають людей, які перебувають поряд. Власні бажання та потреби визначають сутність їхнього буття. Для інших радістю та щастям повинен бути уже сам факт проживання їх на цьому світі. Яскраво це продемонстровано в оповіданні Сухомлинського для дітей «Народження егоїста» (Сухомлинський, 2021, с. 70).

Запобігти проявам такої любові В.О. Сухомлинський намагався шляхом виховання батьківських почуттів. Доносилися істини про батьківські почуття на заняттях педагогічної школи і своєрідних практикумах за спільної участі обох батьків у них (Сухомлинський, 1976, с. 543). Беручи участь у цих практикумах, батьки разом із вчителями організовували діяльність дітей, навчали їх і самі навчалися як вихователі.

У своїй діяльності Василь Олександрович застерігав батьків ще від одного із різновидів нерозумної та інстинктивної любові деспотичної. Підгрунтям цієї любові є егоїзм та безкультур'я батьків. Для них дитина ототожнюється із власною річчю. Дії таких батьків вписуються у модель: моя річ, що зажадаю, те і зроблю.

Окрім егоїзму та безкультур'я батьків, причиною виникнення деспотичної любові $\epsilon$ отриманням окремими із них задоволення від деспотичного захоплення владою над дитиною. Василь Олександрович вважав це явище надзвичайно складним та важким. Оскільки, в атмосфері дріб'язкових причіпок, докорів та звинувачень дитина озлоблюється і перетворюється у самодура. Самодурство своєю чергою виганяє із юної душі той 
душевний порух, який у нормальних сім'ях $\epsilon$ джерелом добра, стриманості та поступливості дітей - ласку. Педагог писав, що той, хто не знав ласки в дитинстві, стає грубим та безсердечним в роки отроцтва та ранньої юності (Сухомлинський, 1976, с. 544). Саме тому у лекціях та бесідах з батьками наголошувалося на недопустимості істеричних скарг, докорів та дріб'язковості у вихованні дітей.

Розкриваючи проблему деспотичної любові, B.О. Сухомлинський наводить приклад різкого переродження дитини із доброї та поступливої, коли була маленькою, у грубу та норовливу, коли підросла. Причину такого явища вчений вбачає у невмінні батька та матері користуватися батьківською владою. Розвиваючи думку, Сухомлинський писав, якщо дитина відчула, що батько та мати по-різному дивляться на поняття «можна», «не можна», «треба», то для неї розумні та необхідні вимоги перетворюються у ту злу силу, яка придушує ії волю. Батькам своєю чергою доводиться дивуватися чому не можна дитину навчити жити без запотиличників, шльопанців, ремінця, палиці.

Окрім любові деспотичної, В. Сухомлинський виділяв ще один різновид нерозумної любові - це любов відкупу. Прихильниками такого різновиду любові, на думку Василя Олександровича, є батьки, які щиро переконанні, що забезпечивши матеріальні потреби дитини, вони успішно виконують свій бать- ківський обов'язок. Матеріальні витрати для них є мірилом батьківської любові до дитини. «Дитина одягнена, взута, сита, здорова, в неї $€$ всі підручники й наочні посібники - що ж вам ще треба» (Сухомлинський, 1976, с. 544).

Таких дітей оточує убозтво і духовна порожнеча. Щоб дітям були доступні тонкі людські почуття, вони серцем відчували, що живуть серед людей, педагогами спільно із батьками було організовано спеціальну школу виховання почуттів. Окрім цієї школи, важливою ділянкою в діяльності батьківської школи було ще формування культури людських бажань (Сухомлинський, 1976, с. 442). Що, на думку Сухомлинського, є стовповою дорогою сімейно - шкільного виховання.

Висновки і перспективи подалыших досліджень. Важливою складовою частиною у творчому доробку Сухомлинського $є$ партнерська взаємодія сім'ї та школи. Умовою цього партнерства є оволодівання сім'єю батьківською педагогікою. Опанування батьківської педагогіки та визначення стратегії спільної діяльності сім'ї та школи відбувалося на заняттях школи для батьків.

Дослідження проблеми партнерської взаємодії сім'ї та школи дозволило визначити перспективи подальших наукових пошуків. На нашу думку, заслуговує на увагу дослідження ролі школи виховання почуттів у забезпеченні педагогіки партнерства у педагогічній спадщині В. О. Сухомлинського.

\section{ЛІТЕРАТУРА:}

1. Білецька I.O., Коберник О.М. Педагогіка партнерства та їі реалізація в творчій спадщині В.О. Сухомлинського. Наукові записки. [Центрального державного педагогічного університету імені Володимира Винниченка]. Випуск 171. Серія: Педагогічні науки. 2018. С. 34-39.

2. Друганова О.М., Білик В.М. Актуальність поглядів В.О. Сухомлинського в умовах розбудови нової української школи. Теорія та методика навчання та виховання. 2019. № 47. С. 26-36.

3. Коменский Я. А., Локк Д., Руссо Ж. - Ж.Ю.Ю., Песталоцци И. Г. Педагогическое наследие / Сост. В. М. Кларин, А. Н. Джуринский. Москва: Педагогика, 1989. 416 с.

4. Кремень В.Г. Педагогіка Василя Сухомлинського: відповіді на запити часу. Голос України. 2018. 20 вересня. С. $8-10$.

5. Макаренко А. С. Книга для батьків. Київ: Рад. школа, 1980. 327 с.

6. Мельник Н. Методичні ідеї педагогічної системи Василя Сухомлинського в контексті Нової української школи. Нова педагогічна думка. 2019. № 3. С. 127-133.

7. Нова українська школа : порадник для вчителя / за заг. ред. Н. М. Бібік. Київ : ЛТД, 2019. 208 с.

8. Остапйовський І., Остапйовська Т. Актуальність ідей В.О. Сухомлинського в реалізації педагогіки партнерства у концепції Нової української школи. Педагогічний часопис Волині. 2020. № 1 (16). С. 32-38.

9. Песталоцци И.Г. Лебединая песня: избранныепед. произведения. Москва:Просвещение, 1965, Т.3.С. 339-568.

10. Петренко О.Б. Трансформація ідеї материнської педагогіки: від Я.А.Коменського до В.О.Сухомлинського. Інноватика у вихованні : зб. наук. пр. Рівне: РДГУ, 2018. Вип. 8. С. 62-82.

11. Сухомлинська О. Василь Сухомлинський крізь призму часу: деякі зауваги до розгляду ідей. Інноватика у вихованні: зб. наук. пр. Рівне: РДГУ, 2020. Вип. 11. Том 1. С. 6-16. 
12. Сухомлинський В. О. Квітка сонця : збірка творів / пер. з рос. Д. Чередниченка; худож. Є. Житник. Харків: ВД «ШКОЛА», 2021. 240 с.

13. Сухомлинський В. О. Лист молодому батькові: вибрані твори. Київ : Рад. школа, 1976, Т. 5. С. 440-446.

14. Сухомлинський В. О. Розмова $з$ молодим директором школи: вибрані твори. Київ: Рад. школа, 1976, T. 4. C. 393-626.

15. Сухомлинський В. О. Сто порад учителеві: вибрані твори. Київ : Рад. школа, 1976, Т. 2. С. 417-654.

16. Ушинский К. Д. Общий взгляд на возникновение наших народных школ: избранные пед. произведения. Москва: Просвещение, 1968. С. 35-47.

\section{REFERENCES:}

1. Biletska, I. O. \& Kobernyk, O. M. (2018). Pedahohika partnerstva ta yii realizatsiia v tvorchii spadshchyni V. O. Sukhomlynskoho [Pedagogy of partnership and its realization in the creative heritage of V. O. Sukhomlinskyi]. Naukovi zapysky. [Tsentralnoho derzhavnoho pedahohichnoho universytetu imeni Volodymyra Vynnychenka]. Seriia: Pedahohichni nauky - Scientific notes. [Tsentralnoho derzhavnoho pedahohichnoho universytetu imeni Volodymyra Vynnychenka]. Series: Pedagogical sciences. 171, 34-39. (in Ukrainian)

2. Druhanova, O. M. \& Bilyk, V. M. (2019). Aktualnist pohliadiv V. O. Sukhomlynskoho v umovakh rozbudovy novoi ukrainskoi shkoly [The relevance of V. O. Sukhomlinsky's views in the conditions of building a new Ukrainian school]. Teoriia ta metodyka navchannia ta vykhovannia - Theory and methods of teaching and education. 47, 26-36. (in Ukrainian)

3. Klarin, V. M. \& Dzhurinskij, A. N. (Eds) (1989). Komenskij, Ja. A., Lokk, D., Russo, Zh. Zh., Pestalocci, I. G. Pedagogicheskoe nasledie [Comenius, J. A., Locke, D., Rousseau, J. J., Pestalozzi, I. G. Pedagogical heritage]. Moskva : Pedagogika. (in Russian)

4. Kremen, V. H. (2018). Pedahohika Vasylia Sukhomlynskoho: vidpovidi na zapyty chasu [Pedagogy of Vasyl Sukhomlynsky: answers to the questions of time]. Holos Ukrainy - Voice of Ukraine. September 20, 8-10. (in Ukrainian)

5. Makarenko, A. S. (1980). Knyha dlia batkiv [A book for parents]. Kyiv : Rad. Shkola. (in Ukrainian)

6. Melnyk, N. (2019). Metodychni idei pedahohichnoi systemy Vasylia Sukhomlynskoho v konteksti Novoi ukrainskoi shkoly [Methodical ideas of Vasyl Sukhomlynskyi's pedagogical system in the context of the New Ukrainian school]. Nova pedahohichna dumka - New pedagogical thought. 3, 127-133. (in Ukrainian)

7. Bibik, N. M. (Eds). (2019). Nova ukrainska shkola: poradnyk dlia vchytelia [New Ukrainian school: a guide for teachers]. Kyiv : LTD (in Ukrainian)

8. Ostapiovskyi I. \& Ostapiovska T. (2020). Aktualnist idei V. O. Sukhomlynskoho v realizatsii pedahohiky partnerstva u kontseptsii Novoi ukrainskoi shkoly [The relevance ideas of V. O. Sukhomlinskyi for the implementation the pedagogy of the partnership in the Concept of the New Ukrainian school]. Pedahohichnyi chasopys Volyni-Pedagogical journal Volyn. 1(16). (in Ukrainian)

9. Pestalocci, I. G. (1965). Lebedinaja pesnja: izbrannye ped. Proizvedenija [Swan song: selected ped. artworks]. (Vol. 3). Moskva: Prosveshhenie (Vol. 3). (in Russian)

10. Petrenko, O. B. (2018). Transformatsiia idei materynskoi pedahohiky: vid Ya. A. Komenskoho do V. O. Sukhomlynskoho [Transformation of the idea of maternal pedagogy: from Comenius to Sukhomlinskyi]. Innovatyka u vykhovanni - Innovation in education. 8, 62-82. (in Ukrainian)

11. Sukhomlynska, O. (2020). Vasyl Sukhomlynskyi kriz pryzmu chasu: deiaki zauvahy do rozghliadu idei [Vasyl Sukhomlynskyi through the prism of time: some remarks on the consideration of ideas]. Innovatyka u vykhovanni Innovation in education. 11(1), 6-16. (in Ukrainian)

12. Sukhomlynskyi, V. O. (2021). Kvitka sontsia [Sun flower]. (D. Cherednychenko, Trans). Kharkiv : VD «ShKOLA» (in Ukrainian)

13. Sukhomlynskyi, V. O. (1976). Lyst molodomu batkovi [Letter to a young father]. (Vols. 5), (pp. 440-446). Kyiv : Rad. shkola (in Ukrainian)

Sukhomlynskyi, V. O. (1976). Rozmova z molodym dyrektorom shkoly [Conversation with a young school principal]. (Vols. 4), (pp. 393-626). Kyiv : Rad. shkola (in Ukrainian)

14. Sukhomlynskyi, V. O. (1976). Sto porad uchytelevi [One hundred tips for teachers]. (Vols. 2), (pp. 417-654). Kyiv : Rad. shkola (in Ukrainian)

15. Ushinskij, K. D. (1968). Obshhij vzgljad na vozniknovenie nashih narodnyh shkol [A general view of the emergence of our folk schools]. Izbrannye ped. proizvedenija-Selected ped. works. (pp. 35-47). Moskva : Prosveshhenie (in Russian) 